\title{
Tłumaczenie bez oryginału, czyli o stylu prozy Maurice'a S. Andrewsa, Joe Alexa i Noëla Randona
}

Rafał Ludwik Górski 


\section{Tłumaczenie bez oryginału, czyli o stylu prozy Maurice'a S. Andrewsa, Joe Alexa i Noëla Randona}

Rafał Ludwik Górski

TEKSTY DRUGIE 2017, NR 5, S. 264-276

DOI: $10.18318 /$ td. $2017.5 \cdot 18$

$\mathbf{Z}$ jawisko „tłumaczeń bez tłumaczenia”, czyli, używając terminu Anny Martuszewskiej', zjawisko kryminału pseudozachodnioeuropejskiego nie jest naszemu literaturoznawstwu nieznane. Przypomnijmy pokrótce: oto w PRL powstają powieści kryminalne, których akcja toczy się w jednym z tzw. krajów kapitalistycznych (najczęściej w Wielkiej Brytanii), tam też mieszkają jej bohaterowie, a autorzy powieści noszą zagraniczne imiona i nazwiska. Wszystko to razem tworzy złudzenie popularnej powieści tłumaczonej na język polski. Nic bardziej mylnego - autorzy tych powieści byli Polakami i pisali je po polsku². Co więcej - gdy występowali pod własnym nazwiskiem,

1 A. Martuszewska Krajobrazy sprawiedliwości, "Teksty” 1973 nr 6, s. 92; A. Martuszewska Niektóre właściwości struktury polskiej współczesnej powieści kryminalnej, w: Formy literatury popularnej. Studia, red. A. Okopień-Sławińska, Ossolineum, Wrocław 1973, s. 96. Joe Alex m.in. na czeski, węgierski i rumuński, słowacki czy bułgarski. Na czeski tłumaczeni byli Maurice S. Andrews i Noël Randon - por. katalog Bibloteki Narodowej. 
ich twórczość w niczym nie przypominała popularnego kryminału. Joe Alex (ale także Kazimierz Kwaśniewski) to znany tłumacz Maciej Słomczyński, Maurice S. Andrews to Andrzej Szczypiorski. Z tej trójki zapewne twórczość Tadeusza Kwiatkowskiego nie była tak odległa od tego, co wydał pod pseudonimem Noël Randon ${ }^{3}$. Dwaj pozostali autorzy - przynajmniej oficjalnie próbują się dystansować od tych tekstów, traktują je jako źródło dochodu (Słomczyński) czy wprawka literacka (Szczypiorski)4.

„Wśród zwolenników kryminałów panuje na ogół przekonanie, że najlepsze powstają w Anglii i Francji”, spekuluje Dobrosława Świerczyńska. „Może dlatego Maciej Słomczyński pisze powieści sensacyjno-kryminalne jako «Joe Alex» (rzadziej jako «Kazimierz Kwaśniewski»), Andrzej Szczypiorski jako «Maurice S. Andrews», a Tadeusz Kwiatkowski m.in. jako «Noël Randon»"5.

„Zagadnieniem wartym zbadania byłoby - czy w tamtym okresie odbiorca, kupujący bądź wypożyczający w bibliotece kolejne tomy kryminalnych serii, miał świadomość, kto ukrywa się za pseudonimami (zwłaszcza w przypadku znanych pisarzy)", stwierdza Krystyna Walc ${ }^{6}$. Pójdźmy w tym pytaniu dalej: czy odbiorca w ogóle miał świadomość, że czyta powieść, która nie jest tłumaczeniem.

Od czasów gdy Mona Baker zaczęła intensywniej badać język przekładu za pomocą narzędzi korpusowych, wiadomo, że ten różni się od języka tekstów nietłumaczonych. To, co go charakteryzuje, to: uproszczenie, dążność do eksplicytności, normalizacja oraz interferencja z językiem oryginału. Ponadto teksty tłumaczone charakteryzuje spłaszczenie (levelling-out): tłumaczenia w porównaniu do oryginałów są mniej idiosynkratyczne i bardziej podobne do siebie ${ }^{7}$. Badania wielokrotnie powtarzane na różnym materiale - zarówno

3 Inni pisarze tego nurtu to: Alen Baxton (właśc. Wiesław Godziemski), Jocelyn Brent (właśc. Jerzyna Słomczyńska), Robert Brutter (właśc. Andrzej Grembowicz), Mike W. Kerrigan (właśc. Andrzej Wydrzyński), Umberto Pesco (właśc. Ireneusz Iredyński), Alex Rovin (właśc. Aleksander Rowiński), Amadeo Visconsini (właśc. Bohdan Władysław Tymieniecki). Za K. Walc Nie tylko powieść milicyjna. Kryminalne serie PRL-u: "Klub Srebrnego Klucza”, "Labirynt” i "Seria z Jamnikiem, w: Literatura i kultura popularna: badania i metody, red. A. Gemra, A. Mazurkiewicz, Pracownia Literatury i Kultury Popularnej oraz Nowych Mediów, Wrocław 2014, s. 137-151.

4 I. Mityk Gra z konwencją detektywistycznq w utworach Joe Alexa i Maurice'a S. Andrewsa „,Studia Pragmalingwistyczne" 2011 III, s. 69-83.

5 D. Świerczyńska Polski pseudonim literacki, PWN, wyd. 2, zmien., rozszerz., Warszawa 1999, s. 27.

6 K. Walc Nie tylko powieść milicyjna, s. 84.

7 M. Baker Corpus-based translation studies: The challenges that lie ahead, w: Terminology, LSP and Translation: Studies in language engineering in honour of Juan C. Sager, ed. by H. Somers, 
tłumaczeń użytkowych, jak i literackich - dowodzą, że jest to wspólna ich cecha, niezależna od języka źródłowego czy docelowego. Stąd też te właściwości przekładu nazywane są uniwersaliami tłumaczeniowymi. Że nie wyzwalają się od nich polscy tłumacze literaccy, wykazał Łukasz Grabowski ${ }^{8}$ w swojej pracy z roku 2013.

Odrębność tekstu tłumaczonego daje się dostrzec również poprzez distant reading (czytanie z oddali), w tym wypadku dzięki metodom stylometrycznym. Ukazały to pionierskie prace Baroniego i Bernardini ${ }^{9}$, Gellerstama ${ }^{10}$ oraz Rybickiego".

Te dwa fakty: swoistość języka tłumaczenia i próba wywołania w czytelniku wrażenia, że ma do czynienia z przekładem, skłaniają do postawienia pytania o to, czy autorom kryminału pseudozachodnioeuropejskiego udawało się również imitować „zachodniość” w warstwie językowej. Czy sztafaż obcości pozostaje tylko na poziomie miejsca akcji i scenografii (nie wyłączając pewnego luksusu, obcego śledczym z Pałacu Mostowskich²), czy iluzję obcości udaje się także stworzyć w języku? A jeśli się udaje, to czy jest to zabieg świadomy? Czy autor raz występujący jako Polak, drugi raz jako obcokrajowiec może zmienić nie tylko nazwisko, ale i styl ${ }^{13}$ ?

John Benjamin Publishing Company, Amsterdam/Philadelphia, s. 175-186. M. Baker Corpus linguistics and translation studies: Implications and applications, w: Text and technology: in honour of John Sinclair, ed. by G. Francis, M. Baker, E. Tognini Bonelli, John Benjamins, Amsterdam, s. 233-252. Por. Ł. Biel Jakość przekładu prawnego i prawniczego w świetle normy Europejskiej pn-en 15038 oraz hipotezy uniwersaliów translatorycznych, „Rocznik Przekładoznawczy, Studia nad teorią, praktyką i dydaktyką przekładu" $2011 \mathrm{nr}$ 6, s. 13-28.

8 Ł. Grabowski Interfacing corpus linguistics and computational stylistics: Translation universals in translational literary Polish. "International Journal of Corpus Linguistics” 2013 No. 18.2, S. 254-280.

9 M. Baroni, S. Bernardini A new approach to the study of Translationese: Machine-learning the difference between original and translated text, "Literary and Linguistic Computing" 2006 No. 21 (3), s. 259-274.

M. Gellerstam Translationese in Swedish novels translated from English, w: Translation Studies in Scandinavia, ed. by L. Wollin, H. Lindquist, CWK Gleerup, Lund 1986, s. 88-95.

11 J. Rybicki Burrowing into translation: character idiolects in Henryk Sienkiewicz's Trilogy and its two English translations, "Literary and Linguistic Computing” 2006 No. 21 (1), s. 91-103. na to pytanie na drodze analizy jakościowej, por. E. Tabakowska Zagadki Joe Alexa, „Przekładaniec" 1999, nr 5, s. 65 . 
Jaki tedy jest język powieści Cicha jak ostatnie tchnienie, Cichym ścigałam go lotem, Czarne okręty (tomy 1-3), Gdzie przykazań brak dziesięciu, Jesteś tylko diabłem, Niechaj odnajda swoich wrogów, Piekło jest we mnie, Powiem wam jak zginąt, Śmierć mówi w moim imieniu, Zmącony spokój Pani Labiryntu Joe Alexa, Dymisja nadinspektora Willburna, Pod szlachetnym koniem, Śledztwo przy ulicy Laos Maurice'a S. Andrewsa oraz Caty ogień na Laleczkę, Weekend w pensjonacie „Cyprys" Noëla Rondona? Czy przypomina on język tłumaczeń? Czy Msza za miasto Arras i Początek Szczypiorskiego, Ladujemy 6 czerwca Słomczyńskiego oraz Śmierć i Kowalski Kazimierza Kwaśniewskiego są stylistycznie odrębne?

Od razu zaznaczmy, że nie jest to pełny zestaw powieści wymienionych autorów, wydanych pod pseudonimem. Dobór materiału badawczego - jak dzieje się w humanistyce cyfrowej niejednokrotnie, choć nie zawsze jawnie był podyktowany przede wszystkim dostępnością tekstów. Wydaje się jednak, że ta ich liczba wystarczy do wyciągnięcia przekonujących wniosków.

By uzyskać odpowiedź na to pytanie, przeprowadziłem trzy eksperymentyza pomocą pakietu Stylo autorstwa Macieja Edera, Jana Rybickiego i Mike'a Kestemonta ${ }^{14}$.

Wszystkie ${ }^{15}$ one mają wspólną podstawę. Otóż polega ona na porównaniu znormalizowanej częstości słowoform w poszczególnych tekstach. I tak np. słowo $i$ stanowi 3,22\% wszystkich słów użytych w Mszy za mieście Arras, 1,73\% w Śledztwie przy ulic Laos czy 1,56\% w Weekendzie w pensjonacie "Cyprys". Same te wielkości niewiele mówią (poza tym oczywiście, że gołym okiem widać różnice w częstości użycia tych słów w poszczególnych tekstach). Jeśli jednak dokonamy takiego porównania w większej liczbie tekstów, a przede wszystkim większej liczby słowoform, to okaże się, że te różnice nie są przypadkowe, ale wynikają ze świadomych czy nieuświadomionych preferencji autora. Jeśli więc weźmiemy 100, 500 czy 1000 najczęstszych słowoform, porównamy ich częstość, a następnie uogólnimy to porównanie ${ }^{16}$, to możemy

14 E. Eder, M. Kestemont, J. Rybicki Stylometry with R: A package for computational text analysis. "R Journal" 2016 No. 16 (1); M. Eder, M. Kestemont, J Rybicki Stylometry with R: a suite of tools, W: Digital Humanities 2013: Conference Abstracts, University of Nebraska-Lincoln, Lincoln 2013, s. 487-489.

15 Jest to niezwykle pobieżny zarys problemu. Świetnym wprowadzeniem jest tekst M. Eder Metody ścisłe w literaturoznawstwie i pułapki pozornego obiektywizmu - przykład stylometrii, „Teksty Drugie" 2014 nr 2, s. 90-105, do którego odsyłam zainteresowanego Czytelnika.

16 Świadomie używam słowa „uogólnimy”, nie zaś „zsumujemy”, gdyż z matematycznego punktu widzenia nie chodzi tu o sumę różnic, ale właśnie pewne uogólnienie różnic i podobieństw, 
stwierdzić, które teksty są do siebie podobne, a które są wyraźnie odmienne. Oczywiście chodzi tu o pewną hierarchię: do tekstu A najbardziej podobny jest tekst $\mathrm{B}$, do nich zaś tekst $\mathrm{C}$, tekst $\mathrm{Z}$ zaś od $\mathrm{A}$ różni się najbardziej. Wielokrotnie powtarzane eksperymenty z tekstami różnych pisarzy, języków czy epok wskazują, że jeśli zastosujemy powyższą procedurę do wytworów pióra kilku autorów, to te, które wyszły spod jednego pióra wykazują największe podobieństwo, wyraźnie większe niż z tymi, które napisał ktoś inny. Istnieją co prawda wyjątki, ale są one rzadkie.

Nieco inną metodą jest uczenie maszynowe: tutaj wyznaczamy dwa zbiory: trenujący i testowy. Jeśli chcemy stwierdzić, czy powieść stworzył pisarz A czy B, to w zbiorze trenującym umieszczamy powieści obu tych pisarzy, zbiorze testowym interesujący nas tekst. Za pomocą odpowiedniego algorytmu sprawdzamy, czy tenże tekst jest bardziej podobny do tekstów pisarza A czy B. Tu nie mówimy już o hierarchii, stwierdzamy tylko większe podobieństwo do jednej z klas ${ }^{17}$.

Dotąd pisałem o tekstach jednego autora, niemniej mutatis mutandis można to samo odnieść do tekstów różnych stylów funkcjonalnych - np. powieści dwu różnych autorów będą z zasady bardziej do siebie podobne niż do podręczników akademickich. Tak samo wreszcie - choć z większą ostrożnością można powiedzieć o literaturze pisanej przez kobiety i mężczyzn. Wreszcie co dla naszej argumentacji jest najistotniejsze - o tekstach nietłumaczonych i thumaczonych.

Przy całej swojej skuteczności metoda ma - z punktu widzenia językoznawcy - ogromną słabość. Otóż chcielibyśmy wiedzieć nie tylko, że język autora A różni się od języka autora $B$; chcielibyśmy przede wszystkim wiedzieć, czym się te języki osobnicze różnią. Oczywiście, jak wspomniałem, jesteśmy w stanie podać różnice we frekwencji dowolnego wyrazu, np. spójnika $i$, tyle że w rzeczywistości indywidualność stylu jest niejako rozproszona po całej liście frekwencyjnej. Sytuacja, gdy pod względem frekwencji pewnego wyrazu jakaś powieść danego pisarza wyraźnie różni się od reszty jego twórczości, nie jest niczym niezwykłym. Możemy tedy stwierdzić, że A i B się różnią, ba, możemy powiedzieć, że na tle innych autorów są sobie bliscy bądź odlegli, ale istota różnicy wymyka się interpretacjom językoznawczym.

i sprowadzenie ich do jednej wielkości. Dodajmy, że istnieje wiele metod, które pozwalają dokonać takiego uogólnienia.

17 Tych klas naturalnie może być znacznie więcej niż dwie, w tym tekście jednak nie wyjdę poza taką dychotomię. 
Również z punktu widzenia literaturoznawcy różnica we frekwencji jakiegoś słowa nie może tłumaczyć nam ani fenomenu geniuszu, ani fenomenu grafomanii. Piszę o tym tak szczegółowo, gdyż pytanie o istotę różnicy nasuwa się samo. Niestety musi ono pozostać bez przekonującej odpowiedzi.

Eksperyment 1 to eksperyment wstępny. Wiadomo ${ }^{18}$, że za pomocą metod uczenia maszynowego da się dość dobrze odróżnić teksty nietłumaczone (pisane oryginalnie w danym języku) od tłumaczonych. Powinniśmy wiedzieć, jaka jest dokładność tej procedury dla współczesnej literatury polskiej. W tym celu stworzyłem korpus składający się z 30 powieści oryginalnie pisanych po polsku i 30 tłumaczeń z języka angielskiego. Następnie z niego wykroiłem trzy podkorpusy: dwadzieścia tekstów polskich i tyleż angielskich znalazło się w zbiorze trenującym, zaś po dziesięć w zbiorze testowym. W kolejnym podkorpusie inna dziesiątka znalazła się w zbiorze testowym, zaś zbiór trenujący został uzupełniony dziesiątką ze zbioru testowego w podkorpusie pierwszym. Tę procedurę ponowiłem, tak żeby każdy tekst dwukrotnie znalazł się w którymś ze zbiorów trenujących i raz w którymś ze zbiorów testowych. Te zmiany warunków testu pozwalają zebrać większą liczbę zdarzeń, co z kolei pozwala wyciągać pewniejsze statystycznie wnioski. Każdy z korpusów został przebadany za pomocą funkcji classify wspomnianego pakietu Stylo ${ }^{19}$.

Wyniki tego testu można określić jako zadowalające, tj. teksty pisane oryginalnie po polsku i tłumaczone z języka angielskiego odróżniane są z dokładnością 95,5\% dla korpusu 1, 88,9\% dla korpusu 2, wreszcie 87,9\% dla korpusu 3, czyli średnio ok. 90\%. W kwestii dokładności trzeba zaznaczyć, że zmiana warunków eksperymentu może skutkować zmianą atrybucji. I tak np. powieść Nurowskiej Dwie mitości jest rozpoznawana jako tłumaczona z angielskiego, gdy obliczamy podobieństwa dla 100 najczęstszych słów, gdy zwiększymy tę liczbę dwukrotnie - zdaje się powieścią oryginalnie pisaną po polsku, po czym dla 300 najczęstszych słów znów jest uznawana za tłumaczenie. Ogółem - jeśli w moim eksperymencie było 137 różnych ustawień liczby branych pod uwagę słów i cullingu ${ }^{20}$ - to powieść Nurowskiej była 76

18 M. Baroni, S. Bernardini A new approach..., M. Gellerstam Translationese...

Ustawienia: od 100-1500 najczęstszych słów, klasyfikacja powtarzana po dodaniu 50 kolejnych najczęstszych słów $(100,150,200$... 1500) oraz z cullingiem od 0\% - 100\% zwiększanych o 20 punktów procentowych. Metoda NSC (Nearest Shrunken Centroids), dystans delta. 
razy uznana za tłumaczenie, a 62 razy za powieść nietłumaczoną. Chciałbym więc w tym miejscu zaznaczyć, że istnieją teksty o takiej wahliwej atrybucji. Zapewne należy tę niepewność interpretować jako wskazówkę, że powieść łączy cechy obu typów tekstu. Z drugiej strony istnieją przypadki, takie jak Dziewczyny do wynajęcia Ireny Matuszkiewicz, które 6 razy zostają rozpoznane jako tłumaczenia, a 132 - jako nietłumaczone. Ogółem na 6o przebadanych tekstów 9 jest choćby jednokrotnie błędnie atrybuowanych.

I jeszcze dwie bardzo istotne dla dalszych wywodów uwagi: po pierwsze, wśród owych 60 książek nie ma takiej, która byłaby w 100\% przypadków atrybuowana błędnie. Po drugie, wszystkie błędne atrybucje działają w jednym kierunku - mianowicie powieści polskie są uznawane za tłumaczenia. Jedyny wyjątek to powieść Krązownik „Titanic” Douglasa Adamsa Terry'ego Jonesa, z tym że jest to jeden raz - dla 100 najczęstszych słów. Innymi słowy - sytuacja, że powieść oryginalnie pisana po polsku przypomina tłumaczenie, jest możliwa, natomiast nie sposób pozbyć się cech tłumaczenia ${ }^{21}$.

W drugim eksperymencie przechodzimy do właściwych badań. Zbiorem treningowym stają się wszystkie teksty oryginalne i tłumaczone, które brały udział w pierwszym eksperymencie. Zbiorem testowym zaś teksty wymienione wyżej oraz dwie powieści Szczypiorskiego Msza za miasto Arras i Początek. Warunki eksperymentu są identyczne jak poprzednio. Ich wyniki przedstawia następująca tabela:

\begin{tabular}{|l|l|c|c|c|c|}
\hline \multicolumn{1}{|c|}{ Autor } & \multicolumn{1}{|c|}{ Tytuł } & $\begin{array}{c}\text { Uznane } \\
\text { za nietłu- } \\
\text { maczone }\end{array}$ & $\begin{array}{c}\text { Uznane } \\
\text { za } \\
\text { tłumaczenia }\end{array}$ & $\begin{array}{c}\% \\
\text { uznanych za } \\
\text { niettuma- } \\
\text {-czone }\end{array}$ & $\begin{array}{c}\% \\
\text { uznanych za } \\
\text { tłuma- } \\
\text { czenia }\end{array}$ \\
\hline $\begin{array}{l}\text { Andrzej } \\
\text { Szczypiorski }\end{array}$ & Msza za miasto Arras & 34 & 103 & $25 \%$ & $75 \%$ \\
\hline $\begin{array}{l}\text { Andrzej } \\
\text { Szczypiorski }\end{array}$ & Początek & 137 & 0 & $100 \%$ & $0 \%$ \\
\hline Joe Alex & Cichajak ostatnie tchnienie & 0 & 137 & $0 \%$ & $100 \%$ \\
\hline Joe Alex & Cichym ścigatam go lotem & 0 & 137 & $0 \%$ & $100 \%$ \\
\hline
\end{tabular}

z góry zadanym procencie tekstów. I tak np. culling na poziomie 20\%, jeśli badamy 30 tekstów, oznacza, że bierze się pod uwagę tylko te słowa, które wystąpiły w minimum 6 tekstach. przypadkowo dobranych książek. Po to by je kategorycznie rozciągnąć na całą literaturę pisaną po polsku, czy też na ten język tłumaczoną potrzeba dużo szerzej zakrojonych badań. 


\begin{tabular}{|c|c|c|c|c|c|}
\hline Autor & Tytuł & $\begin{array}{l}\text { Uznane } \\
\text { za nietłu- } \\
\text { maczone }\end{array}$ & $\begin{array}{c}\text { Uznane } \\
\text { za } \\
\text { tłumaczenia }\end{array}$ & $\begin{array}{c}\% \\
\text { uznanych za } \\
\text { nietłuma- } \\
\text {-czone }\end{array}$ & $\begin{array}{c}\% \\
\text { uznanych za } \\
\text { tłuma- } \\
\text { czenia }\end{array}$ \\
\hline Joe Alex & Czarne okręty (tom 1) & 1 & 136 & $1 \%$ & $99 \%$ \\
\hline Joe Alex & Czarne okręty (tom 2) & 1 & 136 & $1 \%$ & $99 \%$ \\
\hline Joe Alex & Czarne okręty (tom 3) & 1 & 136 & $1 \%$ & $99 \%$ \\
\hline Joe Alex & Czarne okrety (tom 4) & 1 & 136 & $1 \%$ & $99 \%$ \\
\hline Joe Alex & $\begin{array}{l}\text { Gdzie przykazań brak } \\
\text { dziesięciu }\end{array}$ & 0 & 137 & $0 \%$ & $100 \%$ \\
\hline Joe Alex & Jesteś tylko dziabtem & 0 & 137 & $0 \%$ & $100 \%$ \\
\hline Joe Alex & $\begin{array}{l}\text { Niechaj odnajdą swoich } \\
\text { wrogów }\end{array}$ & 1 & 136 & $1 \%$ & $99 \%$ \\
\hline Joe Alex & Piekło jest we mnie & 1 & 136 & $1 \%$ & $99 \%$ \\
\hline Joe Alex & Powiem wam jak zginat & 77 & 60 & $56 \%$ & $44 \%$ \\
\hline Joe Alex & $\begin{array}{l}\text { Śmierćmówi w moim } \\
\text { imieniu }\end{array}$ & 0 & 137 & $0 \%$ & $100 \%$ \\
\hline Joe Alex & $\begin{array}{l}\text { Zmącony spokój pani } \\
\text { labiryntu }\end{array}$ & 0 & 137 & $0 \%$ & $100 \%$ \\
\hline $\begin{array}{l}\text { Kazimierz } \\
\text { Kwaśniewski }\end{array}$ & Śmierći Kowalski & 1 & 136 & $1 \%$ & $99 \%$ \\
\hline $\begin{array}{l}\text { Maciej } \\
\text { Słomczyński }\end{array}$ & Lądujemy 6 czerwca & 136 & 1 & $99 \%$ & $1 \%$ \\
\hline $\begin{array}{l}\text { Maurice S. } \\
\text { Andrews }\end{array}$ & $\begin{array}{l}\text { Dymisja nadinspektora } \\
\text { Willburna }\end{array}$ & 1 & 136 & $1 \%$ & $99 \%$ \\
\hline $\begin{array}{l}\text { Maurice S. } \\
\text { Andrews }\end{array}$ & Pod szlachetynym koniem & 1 & 136 & $1 \%$ & $99 \%$ \\
\hline $\begin{array}{l}\text { Maurice S. } \\
\text { Andrews }\end{array}$ & Śledztwo przy ulicy Laos & 0 & 137 & $0 \%$ & $100 \%$ \\
\hline Noël Rondon & Caty ogień na Laleczkę & 137 & o & $100 \%$ & $0 \%$ \\
\hline Noël Rondon & $\begin{array}{l}\text { Weekend w pensjonacie } \\
\text { „Cyprys }\end{array}$ & 136 & 1 & $99 \%$ & $1 \%$ \\
\hline
\end{tabular}

Z danych zamieszczonych w powyższej tabeli widać wyraźnie, że Joe Alex dokonuje idealnej mimikry - jego teksty są niemal zawsze rozpoznawane jako tłumaczenia. Wyjątkiem jest powieść Powiem wam jak zginąt, która znajduje się gdzieś między obiema kategoriami, raz atrybuowana do 
jednej, raz do drugiej. Ta sama sztuka udaje się Szczypiorskiemu wtedy, gdy przyjmuje angielski pseudonim. Równocześnie autor ten - nie udając obcokrajowca - wciąż nie jest odległy od tłumaczeń w Mszy za miasto Arras ${ }^{22}$. Trochę inaczej jest ze Słomczyńskim - jego debiutancka powieść wydana pod własnym nazwiskiem - Ladujemy 6 czerwca z roku 1947 - nosi cechy tekstu tłumaczonego. Natomiast Śmierć i Kowalski z roku 1962, a więc z okresu twórczości Joe Alexa, stylometrycznie jest tekstem nietłumaczonym. Innymi słowy, debiutant zachowuje się jakby tłumaczył, doświadczony pisarz, świetnie naśladujący tłumaczenia, potrafi zmienić styl i wyzbyć się cech języka tłumaczonego.

Jedyny, któremu mimikra się nie udaje, to Noël Randon. Ten znów niemal bezbłędnie jest rozpoznawany jako Polak. Warto przy tym dodać, że owe 0,7\% kiedy i Szczypiorski, i Randon są rozpoznawani jako tłumaczenia, to atrybucja, gdy brane jest pod uwagę 1300 najczęstszych słów z cullingiem na poziomie $80 \%$.

W tym miejscu warto postawić pytanie, czy jest jeden Szczypiorski, czy też Szczypiorski i Andrews to inni pisarze? Czy autorski odcisk palca Andrzeja Szczypiorskiego jest widoczny również w powieściach pisanych pod pseudonimem? By być precyzyjnym: czy w analizie skupień kryminały pseudozachodnioeuropejskie tego autora będą najbliższe innym jego powieściom? Do odpowiedzi posłuży nam trzeci eksperyment. W nim wstawimy powieści Szczypiorskiego i Andrewsa do trzech różnych korpusów ${ }^{23}$. Dopiero na takim tle teksty jednego autora mogą się skupić w jednym miejscu bądź też w tym tle rozproszyć

Tym razem jednak zastosuję inną technikę statystyczną, a mianowicie bootstrap consensus tree, technikę, która uwypukla różnice między tekstami i przez to znajduje szczególne zastosowanie w atrybucji autorskiej. Polega ona w uproszczeniu na wielokrotnym powtarzaniu eksperymentu

Jak napisałem wyżej, nie da się w prosty sposób powiedzieć, czym w istocie stylometrycznie różni się tekst tłumaczony od nietłumaczonego. Nie sposób więc powiedzieć, jakie elementy języka tłumaczonego przeniknęły do Mszy. Niemniej jednak wyniki eksperymentu wskazują, że jeśli wziąć pod uwagę nie więcej niż 400 najczęstszych słów, Msza jest rozpoznawana jako tłumaczenie, przy większej liczbie słów - jako tekst nietłumaczony. To dowodzi, że w omawianym tekście cechy tłumaczenia objawiają się wyłącznie w słowach częstych, w tym w wyrazach funkcyjnych.

23 W praktyce będą to wszystkie trzy zbiory treningowe. Ich skład nie ma tu istotnego znaczenia, pozostałe teksty będą stanowiły tło dla tekstów, które wyszły spod pióra autora Poczq̨tku i Pod szlachetnym koniem. 
atrybucyjnego ze zmianą warunków (por. wyżej). Na jednej gałęzi wykresu znajdują się tylko te teksty, które niezależnie od wszystkich zmian konfiguracji najczęściej są najbliżej siebie. Ujmując rzecz prościej: chodzi o odfiltrowanie przypadkowego szumu a pozostawienia tego co istotnie jest podobne.

Nim przejdę do prezentacji wyników przedstawię wykres, na którym ukazano podobną analizę 9 powieści, po trzy Gojawiczyńskiej, Berenta i Dołęgi-Mostowicza:

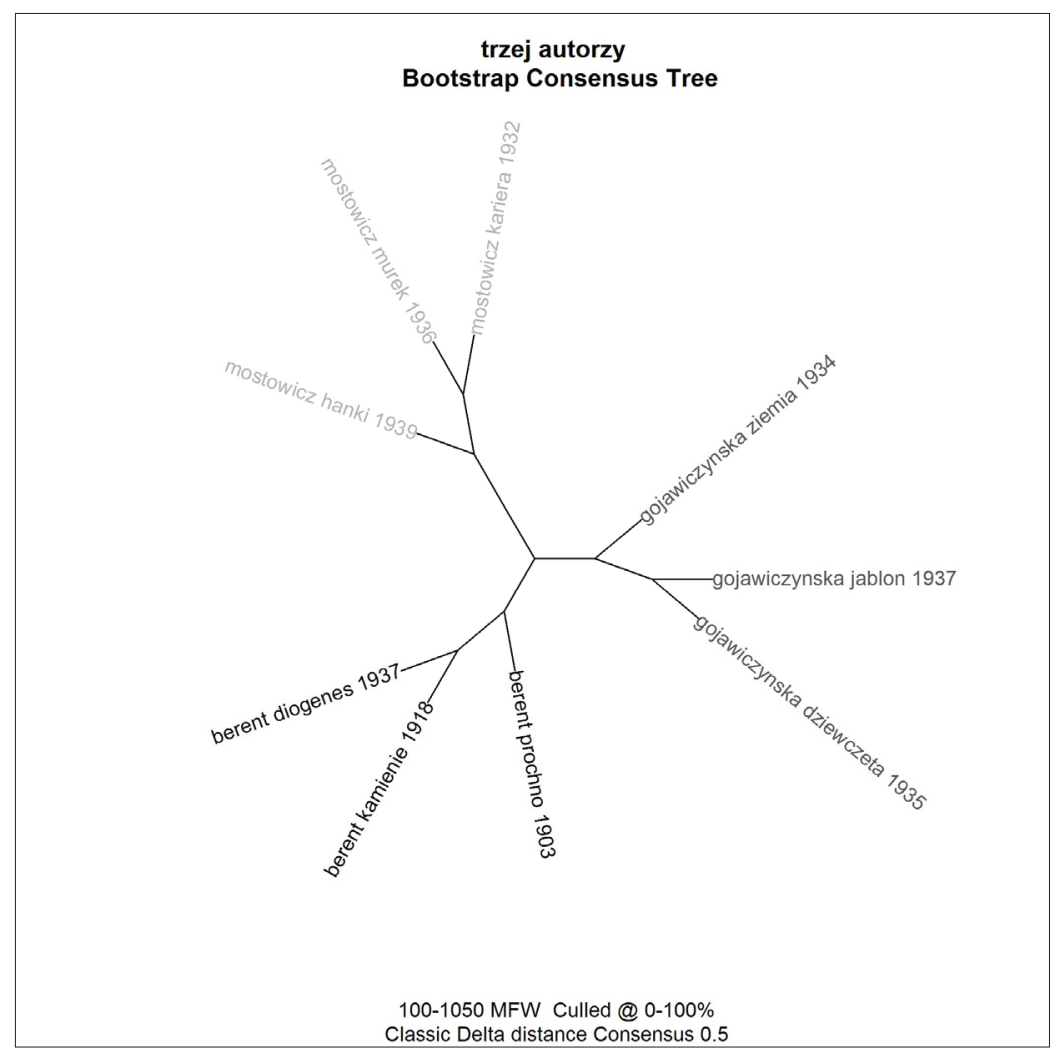

Jak widać powyżej utwory skupiły się na trzech głównych gałęziach, osobnej dla każdego z autorów. 


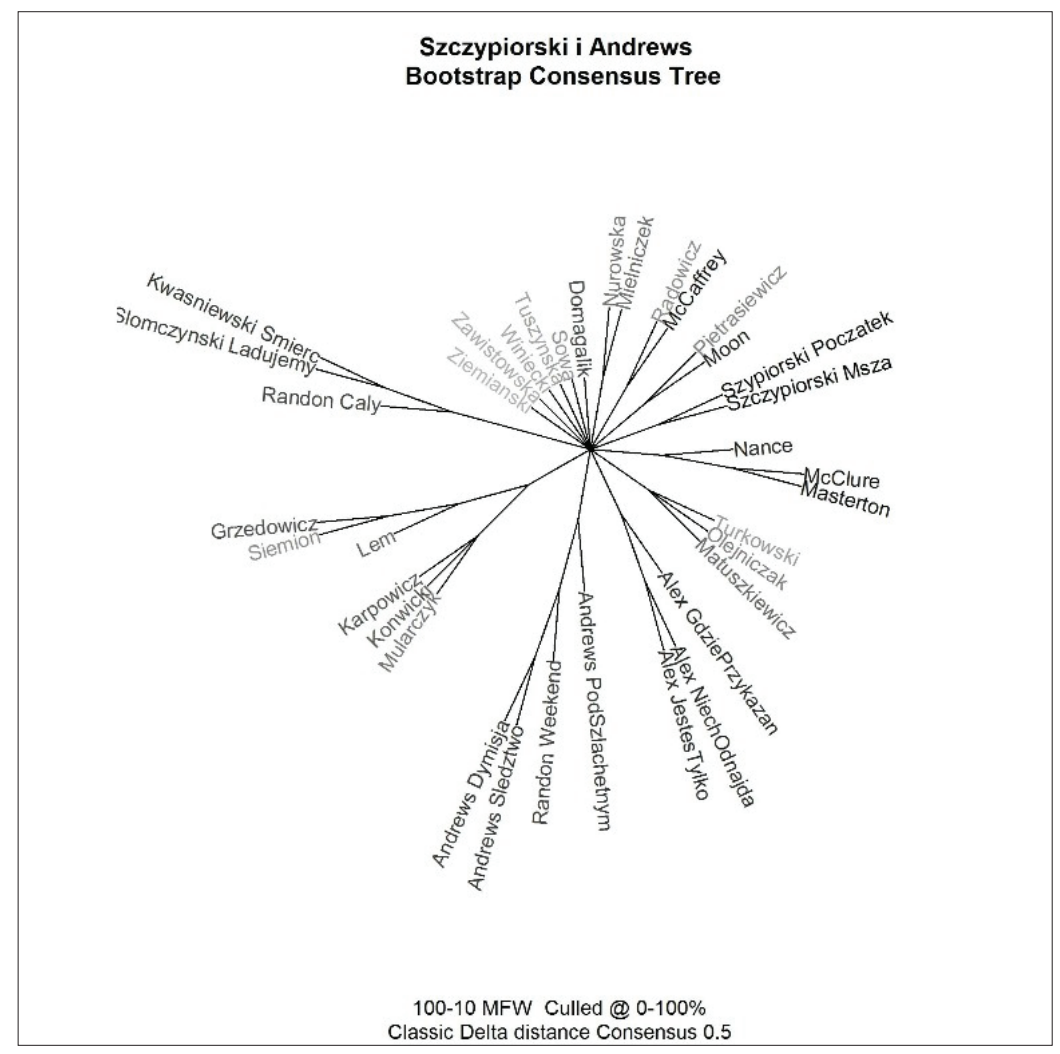

Powyżej zamieszczam jeden tylko wykres, ale we wszystkich wypadkach okazuje się, że powieści Andrewsa grupują się na jednej gałęzi, podobnie powieści Szczypiorskiego, Andrews ze Szczypiorskim nie mają jednak nic wspólnego. Warto też zwrócić uwagę na Randona; otóż we wszystkich trzech wykresach Caty ogień na laleczkę - jest bardzo bliski Alexowi zaś Weekend w pensjonacie „Cyprys" zachowuje się tak, jakby był tekstem Andrewsa. To ostatnie każe podejrzewać, że to właśnie Szczypiorski, a nie jak twierdzi pierwsza strona tego opowiadania, Kwiatkowski jest jego autorem. Opowiadanie to jest zamieszczone w zbiorze Pod szlachetnym koniem, sygnowanym przez trzech interesujących nas autorów, z tym że każde opowiadanie jest podpisane przez jednego z nich. Być może jest to efekt spółki autorskiej Szczypiorski-Kwiatkowski? Spółką można by tłumaczyć fakt, że mimo wszystko tekst ten źle 
oddaje cechy języka tłumaczenia, natomiast Szczypiorski - jak to wykazałem - czyni to świetnie. Nie sposób tego teraz rozstrzygnąć. Podobnie Słomczyński i Kwaśniewski to różni autorzy. Do nich Kwaśniewskiego-Słomczyńskiego dołącza utwór Randona, czyli Kwiatkowskiego ${ }^{24}$.

Istotne jest jednak to, że ten wykres pokazuje bardzo jednoznacznie, że Andrzej Szczypiorski potrafił doskonale wcielać się w podwójną rolę brytyjskiego pisarza kryminałów i jego polskiego tłumacza. Niech nas nie zmyli to, że spośród analizowanych powieści te wydane pod własnym nazwiskiem i te sygnowane pseudonimem zasadniczo różnią się tematyką. Już przy 100 najczęstszych słowach analiza skupień umieszcza te powieści dość daleko od siebie. Tymczasem wśród tych słów znaczna część to słowa synsemantyczne, niezależne przecież od tematu, choć bardzo związane z indywidualnym stylem autorskim; tak częste zaś słowa autosemantyczne to słowa mocno polisemiczne i - by tak rzec - wszędobylskie.

Okazuje się więc, że możliwy jest język tekstów tłumaczonych (tranlationese) bez tłumaczenia. Udaje się to idealnie Andrzejowi Szczypiorskiemu. Pisarz potrafi różnicować swój styl i niewątpliwie zupełnie świadomie naginać go: powieści sygnowane przez Szczypiorskiego i Andrewsa to stylometrycznie książki dwu różnych autorów. Nie udaje się ta sztuka mimikry Tadeuszowi Kwiatkowskiemu, choć trzeba przyznać, że eksperyment wobec niego nie był przeprowadzony całkiem uczciwie - otóż wcielał się on we Francuza nie w Brytyjczyka, tymczasem konfrontowałem go z tłumaczeniami z angielskiego. Idealnym też wcieleniem tłumacza książki bez oryginału jest Maciej Słomczyński. Co prawda Joe Alex to kto inny niż Kazimierz Kwaśniewski i Maciej Słomczyński, nadto Kazimierz Kwaśniewski - to polski pisarz nie tylko z nazwiska, ale i stylu. Tym bardziej jest to zastanawiające, że pierwsza powieść Słomczyńskiego, napisana nim został tłumaczem raczej przypomina tłumaczenie, z kolei ta napisana przez doświadczonego tłumacza brzmi jak oryginał. Zostawiam też bez odpowiedzi ważne pytanie, na ile na jego stylu zaważyła dwujęzyczność.

24 Jeśli w powyższym zbiorze umieścimy wszystkie teksty Słomczyńskiego, to okaże się, że stanowią one całość. Anonimowy recenzent zwrócił mi uwagę na fakt, że w takim zbiorze Słomczyński stanowi 37\% tekstów, co musi zaburzać obraz, gdyż taki korpus składa się niejako ze Słomczyńskiego i nie-Słomczyńskiego. W efekcie zredukowałem liczbę jego tekstów do takiej samej liczby co Szczypiorskiego, tj. do 5. Kilkakrotnie powtarzane testy ze zmianą powieści tego autora dają niejednoznaczny obraz: Kwaśniewski-Słomczyński raz jest, raz nie jest tym samym, kim Joe Alex. 
Stanowi to ciekawy przyczynek do psychologii stylu. Otóż raczej uważa się, że styl jest jak odcisk palca - nie można się go pozbyć, nawet jeśli się tego chce, a wybory leksykalne twórcy nie są do końca świadome. Tu mamy przykład, jak dalece piszący może świadomie kształtować odrębność stylistyczną swoich tekstów.

\section{Abstract}

\section{Rafał L. Górski}

INSTITUTE OFTHE POLISH LANGUAGE OF THE POLISH ACADEMY OF SCIENCES (CRACOW)

Translation without an Original: Style in the Novels of Maurice S. Andrews, Joe Alex and Noël Randon

The so-called 'pseudo-Western-European crime novel' was a phenomenon unique to the literature of the Polish People's Republic. Written in Polish, these novels posed as translations - mostly from English. The stories were set in the UK or in France; writers used foreign-sounding pseudonyms. Górski discusses in how far the authors also managed to imitate translated language. Examining novels by Maciej Słomczyński alias Joe Alex, Andrzej Szczypiorski alias Maurice S. Andrews and Tadeusz Kwiatkowski alias Noël Randon, he demonstrates that the first two succeeded much better than the third. A stylometric analysis of Szczypiorski's output shows in fact that the texts he published under his real name differ so much from the novels that appeared under his pseudonym that they could be taken for the works of a different author.

\section{Keywords}

popular literature, crime story, translated language 